\title{
79 |review essay women and warfare: recent literature and new directions in research
}

\author{
Matthew Brown
}

Battle cries and lullabies: women in war from prehistory to the present Linda Grant De Pauw; University of Oklahoma Press, Norman, Oklahoma, 1998, 432 pp, US\$21.95, HbK ISBN 0806132884

War and gender: how gender shapes the war system and vice versa

Joshua S. Goldstein; Cambridge University Press, Cambridge, 2001, 540 pp, $£ 30.00$, HbK ISBN 0521807166

Women, sexuality and war

Philomena Goodman; Palgrave, Basingstoke, 2002, 192 pp, £47.50, HbK ISBN 0333760867

'The blood of our sons': men, women, and the renegotiation of British citizenship during the great war

Nicoletta Gullace; Palgrave Macmillan, New York, 2002, 320 pp, US\$47.50, HbK ISBN 0312294468

Home/Front: the military, war and gender in twentieth-century Germany Karen Hagemann and Stefanie Schiler-Springorum, (editors); Berg, Oxford, 2002, 256 pp, £50.00, HbK ISBN 1859736653

Fighting for American manhood: how gender politics provoked the SpanishAmerican and Philippine-American wars

Kristine L. Hoganson; Yale University Press, New Haven, 1998, 320 pp, \$47.50, HbK ISBN 0300071817

British women and the Spanish civil war

Angela Jackson; Routledge/Cañada Blanch Studies on Contemporary Spain, London and New York, 2002, £68.00, HbK ISBN 0415277973

Women and civil war: impact, organisations and action Krishna Kumar (editor); Lynne Rienner Publications, Boulder, Co, 2001, 264 pp, US\$19.95, PbK ISBN 1555870461

All the daring of the soldier: women and civil war armies Elizabeth Leonard; W.W. Norton, New York, 1999, 368 pp, US\$27.95, HbK ISBN 0393047121 
The number of books that seek to describe and explain women's involvement in warfare throughout history is large and growing. As the field expands, there is increasingly room to show how women have been represented as soldiers, symbols, victims, booty, motive and followers in warfare and, in the UK, to move beyond the conventional emphasis on the victorious powers in the First and Second World Wars.

Approaches to the subject are increasingly diverse. Some scholars, such as Linda Grant De Pauw, analyse women's involvement in warfare on the basis of an overview of the subject ranging across continents, centuries and even millennia. Others, for example Philomena Goodman and Elizabeth Leonard, generalise from detailed treatments of individual conflicts (the Second World War and the US Civil War, respectively).

One constant in this diverse field is to foreground the extent to which chivalric discourse of rescuing defenceless and downtrodden women from rapists and pillagers has served to justify warfare (Hoganson, 1998: 44-45) and how this has often been juxtaposed 'at home' by ideas of 'patriotic motherhood' (Gullace, 2002: 53). New histories of women and warfare attempt to trace where these discourses meet, often at the dissection of 'home' and 'front', discussed with reference to the lives of women which were not restricted by such artificial limitations.

An ample and growing literature continues to document when and where women fought alongside men as soldiers (De Pauw, 1998; Leonard, 1999). Such research is both useful and important, as women's presence in combat situations necessarily affects the way warfare is conceptualized and fought. Despite a concentration on women's military participation in the First and Second World Wars (see the extensive bibliographies in Gullace (2002: 263-271) and Goodman (2002: 171-176) respectively), these conflicts were by no means exceptional. There were 'uncounted numbers' of women who fought in the Napoleonic Wars (De Pauw, 1998: 136), and in other 19 th-century colonial and republican environments women played crucial roles in determining the outcome of conflict. On occasions women had to disguise themselves as men and fight as 'undercover soldiers' (Leonard, 1999: 274), but often they openly enrolled in military and naval forces in order to fight for a cause, a nation or their own adventuring instinct (see Brewster in this volume). For example, Marie-Angélique Josephine Duchemin veuve Brûlon retired after seven years as a soldier in 1799, and was praised by her (male) subalterns as having 'fought with us with the courage of a heroine' (De Pauw, 1998: 139).

Historians and sociologists have more recently examined the way the presence of women in combat affected the military institutions they served. As part of a wider interest in examining the way that warfare was 'gendered', encompassing the burgeoning numbers of studies of male soldiers' 'masculinities', these admirable works seek to breach the appreciable gap between the genres of gender history and military history. Unsurprisingly, this leads to some abrasive encounters, which 
optimists must hope will 'stimulate a debate in which the understanding of gender is matched by a serious treatment of the military side of war' (Kiesling, 2003: 506). Critics note that some writers seeking to extol female bravery and heroism can be forced to rely upon unsubstantiated rumour or medieval myth, most notably when universalizing authors come to treat the Amazons (Goldstein, 2001: 16-17). The South American Amazons never really existed as a tribe of warrior women, despite the numerous European travellers who set out to find them from the 16 th to 20th centuries (Whitehead, 2003: 135-136). As De Pauw explains, the term had its roots in ancient Greece, originally referring to a 'race of warlike women in Libya'. Rather than dismissing women's warfare as myth, De Pauw re-appropriates the term Amazon to describe any 'women who wage war while organized in allfemale units' (De Pauw, 1998: 22). The study of Amazons, therefore, is removed from myth and given concrete standing as one aspect of women's involvement in warfare.

Moving away from the military, therefore, historians have turned to examine the way women's involvement in warfare contributed to larger and more fundamental changes in society. These works focus on the hope that, despite the dislocation, miseries and hardships always associated with war, it can also 'profoundly affect women's personal well-being, their status and role in the family, their access to economic resources, their political participation and their general attitudes and perceptions. ... [and] also open new opportunities for changing existing gender stratification' (Kumar, 2001: 25). These authors accept, however, that women's patriotic service in warfare has never led directly to wholesale improvement of status or conditions. The Representation of the People Act in Britain 'left a multitude of patriotic women dangling unrepresented below an age bar that it would take many of them years to surmount' (Gullace, 2002: 184). In Hispanic America, well over a century would pass between Independence from Spain, and votes for women. The opportunities that women carved out for themselves from the chaos and wreckage of warfare were much more circumscribed and must be sought by detailed examination of their testimonies and experiences in order to trace biographies and prosopographies.

Individual women's lives 'were irrevocably altered both in personal and political terms' by their experience of warfare (Jackson, 2002: 207). Research on the British women who took part on the republican side in the Spanish Civil War, as soldiers, nurses, spies and translators casts a light into what motivated women to take part in warfare outside of 'patriotic' or 'nationalistic' warring. For Jackson, 'Spain' was the clarion call that offered an opportunity to which they could respond, whatever the mixture of the personal, the ideological, the humanitarian and the political on which their motivation was founded' (Jackson, 2002: 47). Women wanted to help in a practical way, 'from the smallest contribution to the greatest commitment. The melioristic motive was to them, the essential inspiration' (Jackson, 2002: 47). 
Examining the accounts and memories of women who lived through periods of war can reveal something about how 'images and notions of masculinity and femininity were constructed, mobilised and stretched when necessary to protect gender differences' (Goodman, 2002: 158). However, they can also inform as to ways that women were able to take advantage of the unique circumstances of wartime in order to gain independence and opportunities denied to them in peacetime. Tracing these processes entails exploration of complex social and military relations (Hagemann and Schiler-Springorum, 2002: 4) and constant historical contextualization of the experiences of women in warfare according to region, race, and the nature of military mobilization. Only by examining the intersections between military, war and gender, and women's diverse roles at home and on the front as soldiers, spies, nurses, propagandists, and even disaffected protesters, can we get closer to understanding the nature of the changes reaped upon society by wars. The comparative dimension is essential to such a project, and the authors discussed here provide a broad framework for understanding the involvement of women in warfare, and the way such experiences affected all women, whether in active service or at home. This is 'truly a subject on which much has been written and yet which is continually supporting more rich and original research' (Gullace, 2003: 144). The incorporation of lesser-studied regions and conflicts can only enrich our understanding of its themes, and allow fruitful comparative work to prosper.

\section{author biography}

Matthew Brown is a Teaching Fellow at the University of Bristol in the Department of Hispanic, Portuguese and Latin American Studies.

\section{references}

Gullace, N. (2003) 'Women and war in comparative perspective' Gender and History Vol. 15, No. 1: $140-145$.

Kiesling, E.C. (2003) 'Book review' [of Goldstein, War and Gender], War in History Vol. 10, No. 4: 502-504.

Whitehead, N.L. (2003) 'South America/Amazonia: the forest of marvels' in P. Hulme and T. Youngs (2003) editors, The Cambridge Companion to Travel Writing, Cambridge: Cambridge University Press, 122-138.

doi: $10.1057 /$ palgrave.fr. 9400214 